\title{
VOLCANIC CAVES OF EAST AFRICA - AN OVERVIEW
}

\author{
Jim W. Simons *
}

\begin{abstract}
Numerous Tertiary to recent volcanoes are located in East Africa. Thus, much of the region is made up by volcanic rock, which hosts the largest and greatest variety of East Africa's caves. Exploration of volcanic caves has preoccupied members of Cave Exploration Group of East Africa (CEGEA) for the past 30 years. The various publications edited by CEGEA are in this respect a treasure troves of speleological information. In the present paper an overview on the most important volcanic caves and areas are shortly reported.
\end{abstract}

Keywords: vulcanospeleology, lava tubes, East Africa

\section{INTRODUCTION}

From the viewpoint of speleology. East Africa includes a vast area extending from the Indian Ocean to eastern Zaire, and north to south from the Sudan to southern Tanzania, unmatched in its variety of caves and in the magnificence of their settings. Included are: (1) dissolution caves in limestones ranging from recently elevated coral reefs to dense marbles and possibly also in partially soluble agglomerates and tuffs; (2) worldclass lava tube caves, some unitary and others strongly braided, with remarkable sequences of unusual primary and secondary features; (3) volcanic pits much like those in limestone, unrelated to lava tubes; (4) extensive roofed tectonic caves; (5) a few inland "sea caves" formed by wave action of large lakes; (6) a unique pit cave in carbonatite lava described elsewhere in this volume; and (7) some which are difficult to classify.

In East Africa, great uphevals in comparatively recent time have produced great rift valleys running north-south through Kenya, Tanzania and Ethiopia, and along the eastern border of Zaire. These uphevals resulted in the building of numerous Tertiary to Recent volcanic's either within the troughs or along related lateral fault systems. Thus, much of the region is made up of volcanic rocks. Contrary to other regions where limestone is more common, in these volcanic rocks are the largest and the greatest variety of East Africa's caves. Especially in Kenya, exploration of caves in these rugged, scenically spectacular volcanic areas has preoccupied members of the Cave Exploration Group of East Africa (CEGEA) for the past 30 years. The caves of central Kenya thus are known much better than those elsewhere in the region. In the volcanic areas along the eastern Zaire border, speleologists from several other nations have added important contributions. A large literature exists, with one bibliography now quite obsolete (Mills, 1977). The various publications of CEGEA are veritable treasure troves of speleological information, now supplemented by this volume and the field guide for this symposium.

\footnotetext{
* Hon. Chairman, Cave Exploration Group of East Africa - P.O. Box 47363 - Nairobi, Kenya.
} 


\section{LAVA TUBE CAVES OF FAST AFRICA}

The largest and most important caves of East Africa are lava tube caves. All known examples are in Quaternary or Recent flows, although a report of holes seen from the air at the southern tip of Kenya's Tertiary $250 \mathrm{~km}$ long Yatta Plateau is intriguing. In the volcanics on both sides of the eastern border of Zaire (along the Rwanda-Uganda boundaries) Ubuvomo bwa Musanze in Rwanda has a length of $4.56 \mathrm{~km}$ and a vertical extent of $210 \mathrm{~m}$. Nearby Ubuvomo bwa Nyrabadogo is about $1.5 \mathrm{~km}$ long. Total length of the Musanze system is about $5.1 \mathrm{~km}$ (Montserrat i Nebot, 1978). Garama Cave in the nearby Kigesi Diestrict of Uganda is $342 \mathrm{~m}$ long (Schomer and Randall, 1994). Among several in eastern Zaire, a cave along the Kakomeru climbing route of Mt. Nyamulagira is especially impressive (Simons, 1972; Glaser, 1989). In Tanzania, small examples reported elsewhere in this volume are located on Kilimanjaro and others probably exist. Those of Ethiopia are less investigated. A $70 \mathrm{~m}$ lava tube cave has been recorded southeast of Addis Ababa and a smaller example on K'one Volcano (Morton, 1976).

\section{LAVA TUBE CAVES OF KENYA}

Kenya's largest lava tube caves are scattered through the Chyulu range of volcanoes located between Nairobi and Mombasa (Simons, 1998). Nearly 100 caves have been recorded in this area, and dense vegetation undoubtedly hides many others. On its eastern flank is the Leviathan Cave System (Fig. 1,2), including the country's longest and deepest cave. Leviathan Cave proper is $10.5 \mathrm{~km}$ long. The CEGEA working map is several meters long and a few $\mathrm{cm}$ wide, and has not been published. This great cave was discovered through study of aerial photographs. It was first entered by CEGEA in September 1975. Most of its passages were surveyed in a 10-day expedition in April 1976. Scaling poles were needed in later mop-up work. In the north Cbyulu area, more than 20 caves are known. The principal caves here occur in two adjacent groups along a single unitary tube in a flow of olivine basalt more than $20 \mathrm{~km}$ long. The groups are about $1 \mathrm{~km}$ apart. They consist of Hells Teeth and Kimakia Caves (upslope) and Mathioni and Skull Caves (downslope). Kimakia Cave is a two-level cave, and has about $1.4 \mathrm{~km}$ of passages. Its main entrance segments its upper level. The upslope section of the cave is notable for consistently large dimensions and for unusual ruby-red secondary stalactites derived from guano minerals. Downslope beyond a second collapse orifice and a series of notable flow ledges, the tube has the form of a canyon passage $20 \mathrm{~m}$ high at a lavafall $10 \mathrm{~m}$ high. Local collapse of accreted wall linings reveals loose pyroclastics, demonstrating downcutting into earlier materials. Deep guano deposited by the Giant Free-tailed Bat (Otomops martiensenni) in this part of the cave formerly was mined commercially. At that time the cave was known as the Ithundu Mine. An extensive guano-based fauna is present. On one occasion a civet cat was observed eating lowhanging bats here. Several short segments of the master tube exist about $250 \mathrm{~m}$ upslope.

Mathioni Cave (Fig. 3) also has two levels. It has about $1.9 \mathrm{~km}$ of passages, $1.4 \mathrm{~km}$ in the main line. Like Kimakia Cave, its main entrance segments its upper level. Its upslope $600 \mathrm{~m}$ passage was briefly developed as a tourist attraction in 1972, with pathways and wooden staircases (now rotting). Attractive chocolate-colored stalactites and flowstone are present. Near the entrance, a pit with accreted surfaces leads down to a major level, through a lavaball complex where the tube was almost completely obstructed while still conducting lava. Beyond, much of the cave exceeds $20 \mathrm{~m}$ in height and width. Its cross-section is high and narrow, then a flat rectangle. Three "burial cairns" 


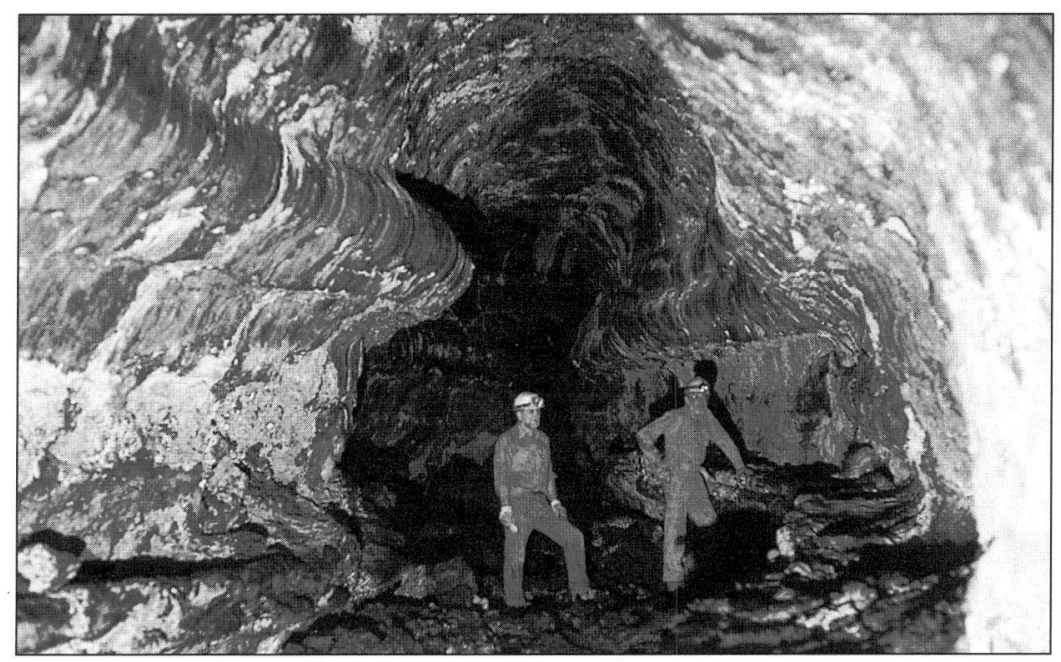

Figure 1. Leviathan Cave, near Discovery Entrance. WRH photo.

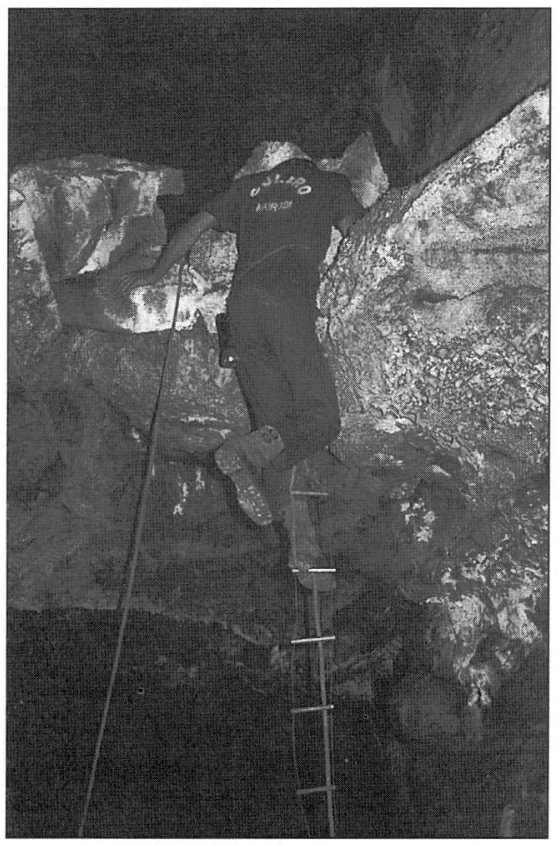

Figure 2. Use of "maypole" to reach The Attic in Leviathan Cave. JWS photo.

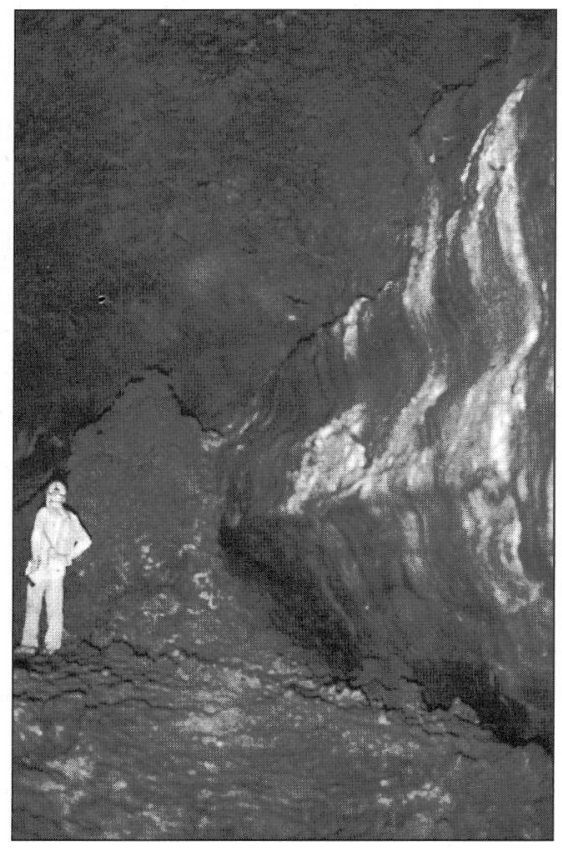

Figure 3. Large conical lava stalagmite in Mathioni Cave. WRH photo. 
are present here, but have not been disturbed to determine what (if anything) lies within. The writer contends that the builders of these cairns must have entered the cave through an upslope entrance closed by invasion of later lava. One such flow of pasty lava obviously entered the cave through a 1-m hole in the ceiling, producing a conical stalagmite about $4 \mathrm{~m}$ high. Another flow blocks the upslope end of the cave. Downslope from this cave are small additional segments of the system. One contains two oxbows.

Mount Suswa is the second major lava tube area known in Kenya. In an area $3 \mathrm{~km}$ square, phonolitic basalt flows extruded after formation of the caldera contain the greatest concentration of lava tube caves in East Africa (Fig. 4). Here some 40 caves are segments of a very complex braided tube system with up to three levels of passages. 67 entrances are recorded. Estimated total passage length is over $11 \mathrm{~km}$. A few of the entrances are recent artificial excavations but most are large roof collapses. 26 caves have a single entrance; the remainder have at least two.

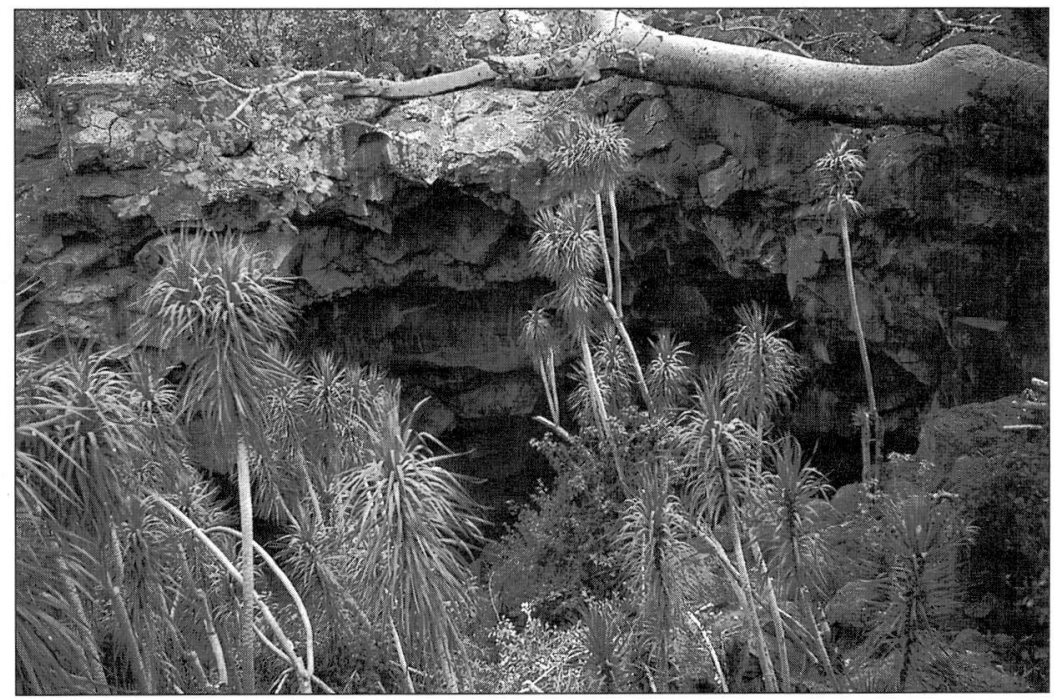

Figure 4. Typical cave entrance, Mt. Suswa. WRH photo.

Three distinct levels of passage exist here. The uppermost lies just below the lava crust and the lowest are 20-35 m below the surface. Superimposition of passage levels is common. Cross-sections of totally infilled tubes seen in cave walls show that the network originally was even more extensive. Passage size varies greatly. Those in the largest systems are consistently 6 to $10 \mathrm{~m}$ in diameter, reaching 20 to $30 \mathrm{~m}$ where breakdown has occurred. Individual passage segments leading off from and between collapses are $10 \mathrm{~m}$ to more than $1 / 2 \mathrm{~km}$ long. What constitutes the overall length of a single cave depends on interpretation of the dripline of collapse holes.

Much exploration remains to be done here, and full plan and profile surveys of known caves in the Main Cave Area remain to be completed. The chance discovery of "Hole in the Floor Tube" in the 23 Series demonstrates the existence of largely unknown extensive lower levels. More detailed surface exploration and "digs" in obvious gaps undoubtedly will yield additional caves.

Unusual treacly lava stalactites are a special feature of Mount Suswa caves (Fig. 5). 


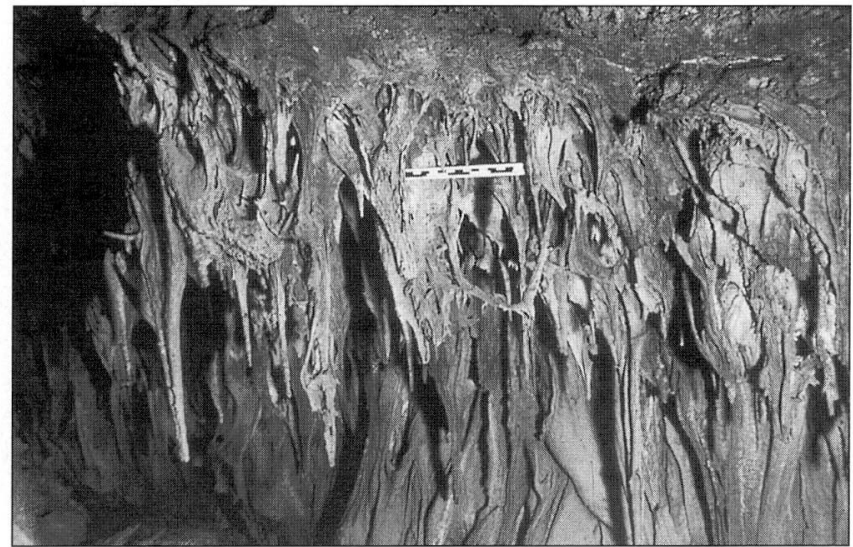

Figure 5. Wind-blown lava stalactites, Mt. Suswa. JWS photo.
Figure 6. Giant hollow pahoehoe ropes, Mt. Suswa. WRH photo.

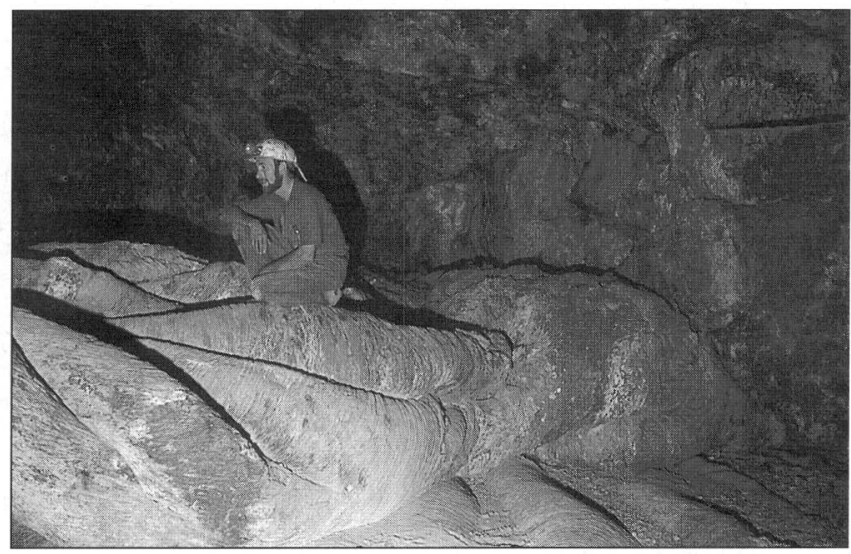

Figure 7. Open channel leading to tube-in-tube, Mt. Suswa. WRH photo. 
Some have the form of wind-blown complexes. Cave 12 contains some especially interesting features. With a few unsurveyed sections, it has a length of a little over $600 \mathrm{~m}$, of which $400 \mathrm{~m}$ is the "Master Tunnel", a tube locally as much as $15 \mathrm{~m}$ wide, with both upper and lower level segments. The northern entrance passages contain some fine lava ropes (Fig. 6) and a corner wall where "dragged lava" forms a notable feature called The Wedding Cake. In the downslope segment of the Master Tunnel one can see a successive series of open channels (Fig. 7), wall benches and tubes attesting to the flow of lava at varying levels. In its uppermost passage, a part of another channel is defined by a raised lip $1 \mathrm{~m}$ high, formed by individual paps of viscous lava congealed one above the other to resemble a man-made wall. Farther along the passage is a magnificent cascade of huge lava ropes. In a nearby side passage leading to a $5 \mathrm{~m}$ pitch into a closed chamber is an array of lava stalactites and small secondary speleothems of mendozite. The unusual form of successively thin to bulbous shapes of the latter suggest that their deposition may be linked to seasonal rainfall. The choked, $160 \mathrm{~m}$ long upslope section of the Master Tunnel also contains a shallow open channel as well as the only example of a lava stalagmite yet found in any Suswa cave. Also present are gutters, wall benches and lava tongues with web-like surfaces. Humid tunnels commonly contain secondary silica-based dripstone and flowstone (Fig. 8). Some has a porcellaneous appearance. Transient precipitates or efflorescences of white salts coat some cave walls after rains.

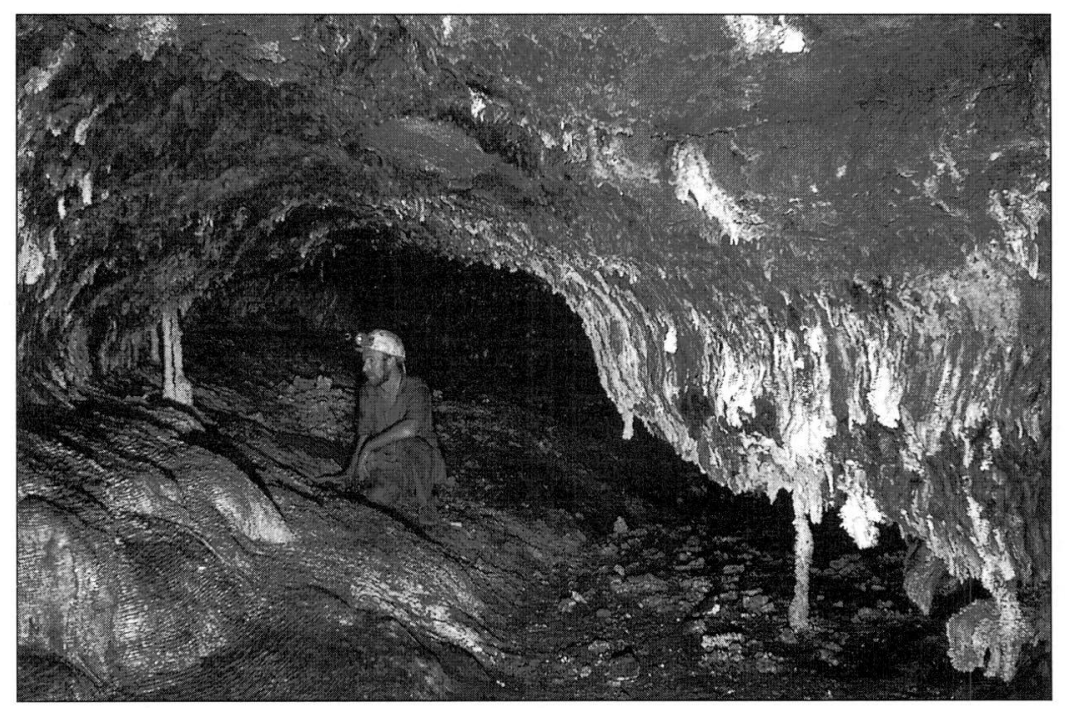

Figure 8. Si02 flowstone and microgours, Mt. Suswa. WRH photo.

Occupation by man in late prehistoric times is shown by obsidian artifacts and the former presence of stone bowls in some caves. During "The Emergency" in the 1950's Mau Mau Freedom Fighters are said to have left certain stone circles with brush enclosures (now largely disintegrated), pottery, and food debris. The present Maasai inhabitants of the mountain do not generally venture far into the caves but do collect honey from beehives in collapse entrances. Some caves have been used as lairs by hyaena and porcupine; both bring in animal bones. Leopards formerly inhabited a number of passages where baboons utilized collapse entrances to feed or to lie up on ledges at night. 
When the caves were first explored in the mid-1960's, remains of the baboons caught by the leopards littered several lairs. Smaller mammals also use the caves, including at least four species of insectivorous bats. Locally, their long habitation gave rise to deep guano deposits which were mined as a source of agricultural fertilizer. A microfauna of several species of beetles is found in the guano tunnels, together with cave crickets, pedipulpids, mites and fleas.

Elsewhere in Kenya, several small caves have been examined in the Elmenteita Badlands north of Mt. Eburru, while a single vent-like cave occurs on the west flank of Menegai Caldera.

The nearby Kilombe Caldera and Loldiani Volcano have yet to be investigated speleologically. In the area around seasonal Lake Tillam, near Korosi Volcano, several lava tube caves are known, while others are reported on nearby Mt. Paka. Many occur on Mt. Silali, north of Lake Baringo, and a major $3 \mathrm{~km}$ cave rivalling those of Mt. Suswa in size has been partially explored here. More lava tube caves are known to occur in the Kabernet region and elsewhere around Lake Baringo, on Emurangogolak Volcano and probably also around Teliki's Volcano on the volcanic barrier between Lake Turkana and the Suguta Valley. Two small, caves have been investigated high in the Nyambeni Mountains near Maua, and other caves are said to exist here. It also is reported that large collapses with caves occur in lava fields surrounding Mt. Marsabit, and cavities often are encountered when digging wells in the Hurri Hills.

\section{CAVES IN TUFF AND AGGLOMERATE}

A great part of central Kenya is an up-domed region of lavas, tuffs, and agglomerates of Tertiary age. Caverns in these tuffs and agglomerates and related lake bed deposits currently comprise almost a third of the caves known in Kenyan volcanic rocks (2596 of all known caves in Kenya). They vary greatly in size and geomorphology. Beneath waterfalls or in valley sides, simple chambers with limited passage development are known along many rivers on both sides of the Rift Valley while on Mt. Elgon, some caves have great breakdown chambers up to $100 \mathrm{~m}$ wide. Elsewhere are small, intricate systems of passages which provide good sport caving. Due to their number and complexity, those along the Ndarugu River (Fig. 9) are especially important. As in the case of other Kenyan caves mentioned in this report, maps and sketches of these caves appear in the symposium guidebook. Similar caves are located near Machakos where Kangundo Cave has more than $300 \mathrm{~m}$ of passage, and on Kilamasimba (Lion Hill) south of Oldonyo Sabuk is a shorter and lower series of stoopways.

On Mt. Elgon (the remnant of a huge Tertiary volcano) are numerous large cave chambers including world-famous Kitum Cave. Their origins are obscured by excavations of salty rock by elephants and other large animals, and by man. A similar situation exists in the caves or "mines" of the Kericho (Lumbwa) area. Here there is a seemingly natural cave below a waterfall of the Jamji River. It provides the novel experience of visiting a streamway while being directly beneath a river. An underwater cave exists in Lake Chala, on the Kenya-Tanzania boundary (Davies, 1972). Caves on the Aberdare Mountains and on Mt. Kenya were used as refuges by the Kikuyu during tribal warfare and the Mau Mau insurgency, as near Maro Moru. Some along the Myamindi, Nithi and Mara Rivers have been reported to be large and extensive. At the northern end of the main Ethiopian Rift, "blister caves" in ignimbrite on Mt. Fantale have been reported in some detail (Gibson, 1974). Two to several dozen meters in diameter and up to $7 \mathrm{~m}$ high, they contain extensive deposits of mammalian bones (Morris, 1974). Shallow lit- 
toral "bat caves" as much as $8 \mathrm{~m}$ high have been reported in cliffs of Lake Rudolph.

At Mt. Elgon, the bedrock is especially rich in soluble salts. Ollier and Harrop (1958) have described some of the caves on the Uganda side of the volcano. Those on the Kenya side, however, now are much better known. Many, but not all of them, have been extensively enlarged by native tribes over a long period of time. Pick marks are locally abundant, and some walls and great fallen blocks have been strangely sculptured. Complex mazes of roof-supporting pillars remain. Some of the pillars are so slender as to seem incapable of supporting any considerable weight or roof span. Indeed, there are legends of miners having been buried under rock falls. Artifacts of this mining remain in some of the caves. Elephant, buffalo, bush buck, and large domestic animals also contribute to enlargement of some of these caves, including Kitum Cave (Fig. 10).

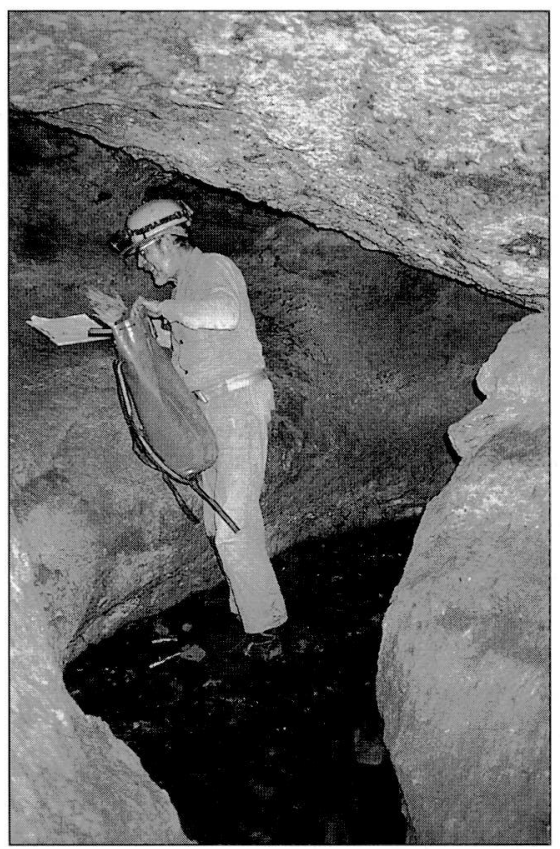

Figure 9. Intermittent stream passage, Ndarugu River cave. WRH photo.

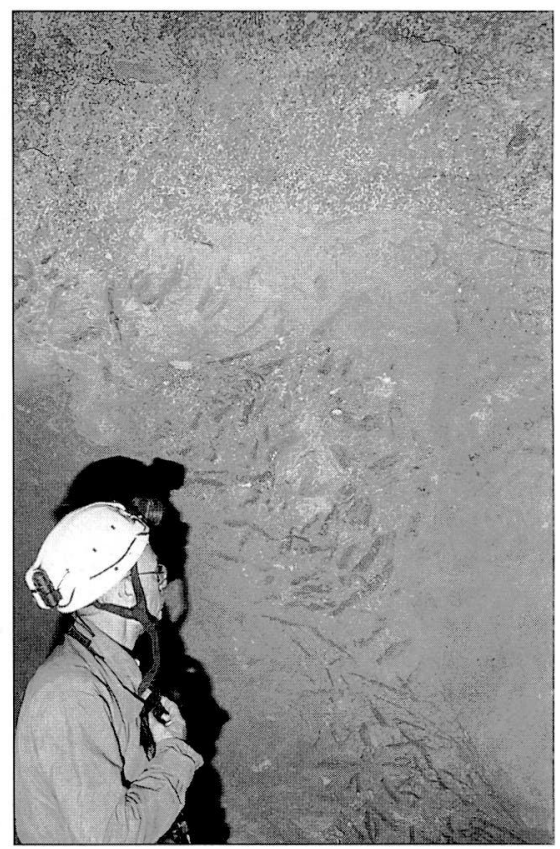

Figure 10. Tusk marks, Kitum Cave. WRH photo.

Toroton Cave is Mt. Elgon's largest cave. More than $1 / 2 \mathrm{~km}$ of chambers and galleries of this type link two entrances. An intervening chamber with a huge roof span is partially supported by seemingly artificial pillars. Between the two entrances but seemingly an independent cave, is Stone Axe Cave. On the opposite bank of the river, at the foot of a waterfall, is Water Cave. Here, part of the river passes into the cave, floods an excavated area, and exits through another large natural portal. Two other caves at the foot of another waterfall on the main Kapkulkul River appear to have been largely excavated by man.

Kimothon Cave (also known as Tweedie's Cave and likely Lindblom's Cave \#1) is at about 2,600 $\mathrm{m}$ in the cliffs of a conspicuous bluff near the Khybe Sawmills on a route 
from Endebess. It consists of a wide chamber visited by elephant and mined galleries leading to a higher chamber with great fallen rocks.

This section formerly was inhabited. The walls were greatly hewn by man, and the cave contains numerous bored stones. Increasingly indistinct crude rock-paintings of animals and a "bowman", are present in a rockshelter outside this cave. Other, betterpreserved multicolored hunting scenes exist in Kakapeli Cave elsewhere on this side of the mountain.

The best-known and most visited caves of Mt. Elgon, however, are Kitum Cave, Makningen Cave, and the Chepyanili Caves. All are located near a popular $4 \times 4$ track in Mt. Elgon National Park. Kitum and Makingnen Cave are described in detail in the guidebook of this symposium (Simons, 1998). Petrified vegetable material and possibly some animal remains are seen in the ceiling walls of these and some other Mt. Elgon caves. Some contain sizeable vugs. The published map of Kitum Cave (Sutcliffe, 1967) was mislabelled Makingnen Cave which is north of Kitum Cave, along the same escarpment. Waterfalls tumble over the mouths of both caves. Makingnen Cave has a huge, high-vaulted entrance. The cave extends northward for about $125 \mathrm{~m}$. The first 60 $\mathrm{m}$ is very wide, flat, dusty, and relatively free of boulders. On its left side is a large, smooth-sided dome which has the appearance of a solutional feature. Near the midpoint of the cave is a large rockfall dividing the cave into two chambers. Many elephant and buffalo footprints and droppings usually are seen in the vast entrance chamber. These animals seem to confine their salt-mining to an excavated alcove on the right side of this chamber. Although droppings have been found on the rockpile, it appears that elephants do not cross it into the back of the cave. The latter is more than $100 \mathrm{~m}$ wide and is occupied by a great central pile of fallen roof slabs up to $8 \mathrm{~m}$ high. Here there are several small pools of water, and a colony of fruit bats.

With so much non-geologic enlargement of these caves, their origin is unclear. More than 30 years ago (Sutcliffe, 1967) it was suggested that their origin was solutional, with later enlargement by mining by man and animals. Small solutional tubes are present at the entrance of Kitum Cave, and smooth roofs and domes in Makingnen Caves suggest that ground water in the partially soluble pyroclastics played an initial part. Many of the caves are associated with river valleys and waterfalls, and it is possible that early ground water cavities were broken into and subsequently enlarged by rivers. Water Cave clearly is undergoing such action at the present time, by a tributary of the Kapkulkul River. Although much of the great size of Toroton Cave is clearly the result of human mining, it is difficult to attribute the great size of some of the underground chambers to the hand of man with simple tools, short of creation of huge rock falls by mining activity. Despite all the evidence of mining by man and wild and domestic animals, the writer agrees that these caves are mostly natural, with chance discoveries of salty rock leading to mining by animals and humans.

Finally, it should be noted that early reports of the Mt. Elgon caves and cavedwellers gave inspiration to the novelist H. Rider Haggard (who visited the coast of Kenya) for his famous book King Solomon's Mines.

\section{TECTONIC RIFTS IN VOLCANIC ROCKS}

Some rifts in granitic rocks have been descended in Kenya. However, open or roofed rifts are more commonly associated with movements of graben blocks along the edges of or within the Rift Valley and on individual volcanos. Most have been revealed and/or enlarged through their taking surface water. Such caves no doubt undergo repeat- 
ed change with monsoons. In the Nakuru area near Menengai Caldera, rifts continually appear during the rains. A 1928 earthquake measuring 7.0 on the Richter Scale, resulted in movement of blocks of relatively hard tuffs, forming escarpments $10 \mathrm{~m}$ high and many fissures. It also diverted the Subukia River underground. Fissures on the former Milton's and Reynold's Farms, near Solai, have been descended by CEGEA members to depths of around $30 \mathrm{~m}$. The Main Rift on Rey- nold's Farm clearly showed enlargement at depth by the passage of water. It was followed laterally for over $130 \mathrm{~m}$ before it became too narrow to continue. At the bottom of several such rifts are dehydrated carcasses of domestic animals.

Other kinds of rifts are known in very loose pyroclastics or ,,earths" which perhaps form an overburden conceiling deepseated faults. Kilimabogo Pot, a $60 \mathrm{~m}$ shaft broken into two pitches, is one of Kenya's deepest caves. It is on the north side of Mt. Eburru. At the southern foot of the same volcano is "The River Sink", a deep open rift which forms a sheer end-wall to a river valley. A seasonal river flows off the mountain and disappears into the rift at the foot of the wall. It is choked with silt and boulders. West of Lake Naivasha, on the Mau Escarpment, Merrick's Pot is another earth rift, $25 \mathrm{~m}$ deep. Mummut N'gei (Maasai for "The Cave of God") on the Ndabibi Plains at the foot of the scarp is clearly on a fault line within old lake sediments and interbedded pumices. It has been enlarged into a cave with $196 \mathrm{~m}$ of passages, mostly walkable.

\section{ACKNOWLEDGMENTS}

In this report, the writer has made free use of information in archives and publications of the Cave Exploration Group of East Africa, for which grateful thanks are extended. various geological maps and other data are the observations and interpretations of the writer and are his sole responsibility. Special thanks go to the author's longsuffering wife for assistance far beyond the call of duty, and to Dr. William R. Halliday, for additional data and for preparation of the first draft of this report at a time of crisis.

\section{REFERENCES}

DAVIES, G. 1972. Caves, crabs, and crocodiles. CEGEA Bulletin 3, p. 9.

GIBSON, I.L. 1974. Blister caves associated with an Ethiopian ash-flow tuff. Stud. Speleol. Vol. 2, part 6, p. 225.

GLASER, S. 1989. Dachungel, vulkane und - eine Höhle. Der Schlaz, no. 58, June, p. 32.

MILLS, M.T. 1977. The subterreanean wonders of Kenya. Shepton Mallet Caving Club (U.K.) Occ. Publ. no. 8, Spring, $19 \mathrm{p}$.

MONTSERRAT I NEBOT, A. 1979. Rwanda 77. Espeleoleg no. XXVIII, March p. 536.

MORRIS, P. 1974. The mammal fauna of the ash-flow tuff blisters of Fantale, Ethiopia. Stud. Speleol. Vol. 2, part 6, p. 233.

MORTON B. (attributed) 1976. New cave discoveries in Ethiopia. CEGEA News 1. Nov.-Dec. p. 1.

OLLIER, C.D. AND J.F. HARROP. 1958. The caves of Mt. Elgon. Uganda Jour., Vol. 22, no. 2, Sept., p. 158.

SCHOMER, B. AND B. RANDALL. 1994. Garama Cave, Mgahinga Gorilla National Park, Kisoro, Kigesi District, Uganda. Unpublished report and map, Feb.

SIMONS, J.W.E. 1972. Lava tunnel on Nyamulagira, Zaire. CEGEA Bulletin 3, p. 19.

SIMONS, J.W.E. 1998. Guidebook of the 8th International Symposium on Vulcanospeleology. Privately published. Feb.

SUTCLIFFE, A. 1967. A caving expedition to East Africa. Wm. Pengelly Cave Studies Assn. Newsl. no. 9, Sept., p. 17

SUTCLIFFE, A. 1973. Caves of the East African Rift Valley. Cave Rsch. Group Trans. Vol. 15, no. 1, Feb., p. 41. 